The Philosophical Journal of Conflict and Violence

Vol. I, Issue 2/2017

(C) The Authors, 2017

Available online at http://trivent-publishing.eu/

\title{
Humbert, David. Violence in the Films of Alfred Hitchcock: A
} Study in Mimesis

East Lansing: Michigan State University Press, 2017. xxv + 174 pp.

Alfred Hitchcock, widely acknowledged as one of the greatest film directors of all time, was a master of cinematic violence, having crafted films pervaded by a sense of menace that often builds to disturbing and sometimes macabre outbreaks of savage victimization. But, as David Humbert argues in Violence in the Films of Alfred Hitchcock: A Study in Mimesis, Hitchcock was also an astute observer of human nature, whose dedication to his muse led him to insights similar to those René Girard arrived at through his study of literature. The subtitle of Humbert's book, A Study in Mimesis, may refer to his own study of Hitchcock's films, but it could also serve as a description of any number of those films, inasmuch as they constitute "studies" in the mimetic dynamics of desire and victimization, comparable in this respect to the great European novels that were the subject of Girard's first book. Humbert offers masterful readings of seven of Hitchcock's most renowned films (The Birds, Shadow of a Doubt, Rope, Strangers on a Train, The Wrong Man, Vertigo, and Psycho) locating the source of the conflicts driving their plots in the mimetic propensities of their characters. In so doing, Humbert bucks the trend of much of the contemporary Hitchcock film criticism, which, influenced by psychoanalytic theory, traces these conflicts instead to drives rooted in perversely libidinous desire. Throughout his book, Humbert contrasts his mimetic reading of Hitchcock with the psychoanalytic interpretations of such critics as Robin Wood and Slavoj Žižek, making Violence in the Films of Alfred Hitchcock not only a significant contribution to our understanding of Hitchcock's oeuvre and an excellent introduction to mimetic theory (indeed, the range and richness of the insights it gleans from Hitchcock's films invites comparison to Deceit, Desire and the Novel) but also a revealing case study in how the interpretative power of mimetic theory compares with psychoanalysis.

Psychoanalytic theory, especially as elaborated by its founding figure Sigmund Freud and his famous French disciple Jacques Lacan, has become one of the most widely used theoretical tools for examining the form and content of cinematic art. The films of Alfred Hitchcock (built around such classic psychoanalytic themes such as anxiety, voyeurism, obsession, narcissism, and the danger of disordered desires roiling beneath the deceptively calm surface of ordinary life) have offered a fertile terrain for psychoanalytic interpretations, so much so that Slavoj Žižek titled his 1992 edited collection of essays on Hitchcock Everything You Always Wanted to Know About Lacan (But Were Afraid to Ask Hitchcock). But if 
the films of Hitchcock can be used to illumine psychoanalytic theory and vice versa, Humbert shows that this relation obtains just as much, if not more so, with respect to Hitchcock and mimetic theory. Indeed, in his back cover blurb, Jean-Pierre Dupruy suggests that Humbert's book could have been titled Everytbing You Always Wanted to Know About Girard (But Were Afraid to Ask Hitchcock). Girard's theory shares much in common with the insights of psychoanalysis, yet it corrects and extends them in important ways. His nearness to Lacan is evident in their common concern with the role of the other in the formation of desire and in the rivalry thereby engendered, though Lacan (following Alexandre Kojève) puts the accent on desire for recognition by the other, which Girard treats as a secondary and derivative phenomenon. As for Freud, Girard regards him as an important precursor to mimetic theory, whose accounts of the Oedipus complex and the founding murder brought him to the very threshold of Girard's own discoveries. However, Freud never grasped the fundamental role of mimesis and so mistakenly assigned the libido a fixed object (the mother) and antagonist (the father), failing to appreciate the underlying mimetic dynamic governing the selection of these-but not only these-objects. One of the great strengths of Humbert's book is that it shows how much remains invisible to the standard psychoanalytic interpretation of Hitchcock and by extension how much of human experience it generally leaves unmapped, while revealing the power of mimetic theory to bring sunlight to those dark corners.

Humbert's discussion of the seven Hitchcock films follows the chronological order of their release dates, with the exception of 1963's The Birds, which Humbert treats first. "One of the key yardsticks by which René Girard demonstrates the truth of his theory," he writes, "is the degree to which it illuminates key aspects of canonical literature that remain unexplained or were passed over in silence." (1). The Birds offers a promising test case, both because of the huge volume of critical studies it has already generated and because of the prominence of a number of themes central to Girard's hermeneutic (the scapegoat, the double, violent escalation) whose significance Humbert believes has eluded previous critics. The central puzzle of The Birds, left unexplained in the film itself, is why the birds attack. Psychoanalytically-minded interpreters typically consider the attack of the birds to represent an outbreak of repressed incestuous desire or maternal superego, the catalyst being the sudden appearance of socialite Melanie Daniels in Bodega Bay, with its disruption of the relationship between Mitch Brenner and his mother Lydia. This particular triangle fits poorly with the classic Freudian Oedipal model, however. In contrast, Humbert connects The Birds with other aspects of the Oedipus myth. Like Oedipus, Melanie is both an insider and an outsider, a figure of high social status as displayed in her elegant attire and manner, but also a stranger to the insular community of Bodega Bay. As such, she is eminently eligible for the office of scapegoat when the town seeks someone to blame for the frightening behavior of the birds. The avian attack on Melanie in the phone booth outside the café is the prelude to her victimization by the townspeople inside the café. Both dramatize her selection as the scapegoat. Though the theme of the scapegoat, the innocent victim, and the falsely-accused recurs frequently in Hitchcock's corpus, Humbert points out that The Birds is unique in depicting scapegoating as concomitant with a total civilizational collapse. The role of the birds is therefore the same as the plague in Girard's reading of 
ancient myths, the Oedipus myth in particular. It serves as an allegory for an epidemic of mimetic contagion and the frenzy it unleashes, which must consummate itself in an act of scapegoating. An analysis of The Birds that treats this social crisis as representing an upsurge of libidinous desire ignores the many clues within the film as to its essentially social and mimetic origins.

This summary of Humbert's analysis of The Birds skips over many details through which he builds his case, details that in their cumulative impact are utterly persuasive. One of those details concerns the muted rivalry between Melanie and Mitch's former girlfriend Annie Hayworth. While most commentators are preoccupied with the conflict between Melanie and Lydia, Humbert astutely notes how Hitchcock artfully composes a number of shots to provide visual clues that Annie and Melanie (Mel-annie) should be seen as doubles. But the doubling of Melanie and Annie is just one instance of a proliferation of doubles in Hitchcock's films (Uncle Charlie and Young Charlie in Shadow of a Doubt, Philip and Brandon in Rope, Bruno and Guy in Strangers on a Train) which, as Humbert points out, the director effectively highlights not only narratively, but also visually. For Humbert, the use of these visual clues signals Hitchcock's awareness of how mimetic rivalry generates doubles and vice versa. But this attention to visual doubling is only one instance of Humbert insightfully bringing into view the tremendous amount of information Hitchcock is able to convey through the composition, framing, and sequencing of his shots and positioning of his camera. The close-ups on the looks and glances that pass between characters in Hitchcock's films, especially in The Wrong Man, is another facet of his directorial style that Humbert finds chockfull of meaning. The contagion of desire and other emotions is hard to portray on screen, but Hitchcock does so effectively in a crucial scene in The Wrong Man, where we are made to feel the escalation of fear and persecutory fervor through the looks exchanged by the tellers in the bank, a scene framed in way that "emphasizes that their desires are not autonomous." (82). Whether libidinous or persecutory, the look in Hitchcock's films does not peer out from some inner Cartesian theatre, an isolated spectator sheltered behind a peephole, but is rather one node in a wider network of mimetic transactions that determines its direction and demeanor.

Humbert also breaks with many contemporary critics in his attention to religious (specifically Catholic) themes in Hitchcock's films, in particular the 'transfer of guilt' that an earlier generation of critics had identified as one of the director's principal motifs. For Humbert, this theme is always bound up with the innocent victim of communal violence, either meted out by a mob or in the more respectable but no less cruel form of judicial condemnation. Melanie Daniels and Manny Balestrero, the eponymous protagonist of The Wrong Man, each fit this description, as does Vertigo's Scottie Ferguson. Humbert underscores how Scottie becomes both the victim and the double of Gavin Elston, his wealthy and powerful friend from college, who hires him to follow Elston's wife. Through Elston's adroit construction of the alluring but ultimately inaccessible faux "Madeleine," Scottie's "wandering" desire is given an idealized object on which to fixate, replete with plenty of obstacles to bring that desire to an intoxicating pitch, all of which part of Elston's plot to murder the real Madeleine, his wife, and transfer the guilt onto Scottie. Scottie becomes Elston's double when he later encounters Judy Barton, the young woman who had 
played the part of Madeleine in Elston's charade. After browbeating Judy into transforming herself into Madeleine once again, Scottie recklessly causes her death, mirroring both the actions and the guilt of his own victimizer. Humbert's analysis of Vertigo is rich and complex, but one of his observations bears special mention. As he sees it, much of the tragedy of the film lies in the fact that, though Judy truly loves Scottie and under less tortured circumstances he could almost certainly love her in return, the subterfuges and intrigues imposed on their relationship have choked off any possibility that they might find authentic renewal and transcendence through a romantic union. Yet Humbert sees this possibility of true love as a genuinely missed opportunity for the two ill-fated lovers. Against those who argue that erotic hungers are always destructive and destabilizing forces in Hitchcock's cinematic universe, Humbert maintains that "Hitchcock sees desire as both fallen and capable of transcendence, both potentially narcissistic and constitutive of satisfying social bonds." (100). This recognition of the ambivalent character of desire accords well with a traditional religious understanding of the human condition, according to which our present fallen state does not exhaust our existential possibilities.

Finally, the fruitfulness of Humbert's approach can be seen in his highly original analysis of Hitchcock's masterpiece Psycho, which, on a standard psychoanalytic interpretation, is the story of a serial killer in the grip of an unresolved Oedipal complex. But what this obsession with Norman Bates' supposedly incestuous desires obscures is that Psycho is in important respects "a tale of parental indifference and cruelty." (117). Humbert invites us to reflect on the real nature of the relationship between Norman and his mother, as we hear it echoed down to the present in his deranged imitation of her scornful and demanding voice. Norman comes to light as not just a mentally-disturbed murderer, but above all as the victim of prolonged maternal tyranny, his mind having finally snapped after a lifetime of psychological and verbal abuse. On this reading, which is consistent with the etiology of his illness described by psychiatrist Fred Richman in the film, Norman killed his mother and her lover not out of some incestuous passion, but rather because his perfectly ordinary and understandable desire for maternal love and respect had suffered the affront of the appearance of a rival whom mother clearly preferred over him. When his mind snapped, he took on the persona of his former persecutor, with his attack on Marion Crane being an imitation of his mother's own punitive wrath. Humbert also astutely observes that Norman's attack on Marion mirrors the retributive fury of her boss and the oilman Tom Cassidy, from whom she stole $\$ 40,000$ in cash. Though the prelude to Norman's attack may have been an act of voyeurism, Humbert shows that the meaning of Norman's violence is ultimately punitive rather than sexual. As with the other films discussed in this book, Humbert's analysis of Psycho offers a wealth of insights of which we have here barely scratched the surface. Perhaps one of the best things that I can say about Humbert's book is that reading it has greatly enhanced not only my understanding but also my enjoyment of these films, bringing into sharp focus so many aspects of Hitchcock's artistry that had hitherto eluded me.

The remarkable fecundity of René Girard's mimetic theory is attested by its fruitful application across a wide variety of disciplines, from theology to economics to conflict studies. But however well traveled, its birthplace is the study of literature and in some sense 
that remains its natural habitat. For Girard, great literature is a privileged domain for the investigation of the mimetic vagaries of human desire, a place where we often encounter psychological insights more subtle than most of us are capable of arriving at without the help of great artists and their faithful mimesis of the human world. Indeed, one of the strongest pieces of evidence for mimetic theory is how the insights of the great novelists converge, each in his unique way depicting the borrowed nature of desire and the conflicts it sets in motion. Girard never ventured far into film criticism, the notable exception being his review of Mel Gibson's Passion of the Christ, in which he bade readers to "think of cinema as extending and surpassing the techniques of great literary and pictorial realism." If the realism of great literature consists in ripping away the veil of illusions generated by human desire, then one might reasonably expect this revelatory power to be equally present of the greatest works of cinema. David Humbert's Violence in the Films of Alfred Hitchcock: A Study in Mimesis shows that this expectation is not mistaken, demonstrating that for Hitchcock "desire is ... not like a Freudian guided missile but a kind of leaf blown in the wind," the wind being the mediating influence of others (102). What Humbert has accomplished in this work should serve as a touchstone for future studies of violence and mimesis in the world of film.

George A. Dunn

University of Indianapolis, USA

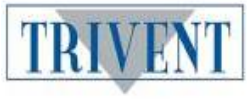

The PJCV Journal is published by Trivent Publishing.

1 "On Mel Gibson's The Passion of the Christ" in Anthropoetics X, no. 1, Spring/Summer, 2004 (first published in Le Figaro Magazine in March 2004, under the title, "A propos du film de Mel Gibson, La Passion du Christ"), http://anthropoetics.ucla.edu/ap1001/rggibson/ (accessed December 5, 2017). 